\title{
Instructor Opinions on the Use of Turkish Folk Music of Syncopated Style in Cello Training
}

\author{
Taner Topaloğlu ${ }^{1} \&$ Şebnem Yıldırım Orhan ${ }^{2}$ \\ ${ }^{1}$ Faculty of Education, Department of Fine Arts Education, Harran Üniversity, Şanlıurfa, Turkey \\ ${ }^{2}$ Faculty of Education, Department of Fine Arts Education, Gazi Üniversity, Ankara, Turkey \\ Correspondence: Taner Topaloğlu, Faculty of Education, Department of Fine Arts Education, Harran Üniversity, \\ Şanlıurfa, Turkey.
}

Received: July 24, 2018

Accepted: September 6, 2018

Online Published: October 23, 2018

doi:10.5539/jel.v7n6p165

URL: https://doi.org/10.5539/jel.v7n6p165

\begin{abstract}
The ability of the music teacher to provide a more qualified education in the professional life and to express himself musically is directly proportional to the quality of the previous instrument training. Studies revealed that the Turkish music products are not used sufficiently in the instrument training given by the institutions of music education and the inadequacy of the customized Turkish music products for use in education.

From this point of view, the aim of this study is to determine the usage status of works and studies of Turkish folk music of syncopated style arranged for cello training and the effects of theoretical knowledge, technical and musical readiness on performing works with syncopated method and to determine the effects of their level and to reveal the problems experienced by the students and to offer solutions for these problems in the direction of the opinions of the instructors who give cello training to music teacher education undergraduates.

The data were collected through a semi-structured interview form developed by the researcher. In the analysis of the collected data, descriptive analysis method was used from qualitative research methods.

When the data were analyzed, it can be concluded that Turkish folk music works and studies of syncopated style used in cello education are numerically inadequate, that the limited available resources are higher than the levels of the students, and that the students have a good theoretical knowledge level about the subject but the levels of readiness in terms of cello techniques in practice are insufficient to perform these tunes. The most important problems experienced by students in performing these melodies are level difficulty, sight-reading, left hand position shifts and use of bows.
\end{abstract}

Keywords: syncopated style, study, music education, Turkish folk music, cello education

\section{Introduction}

In today's educational system, three general subject areas called science, art and technique are being tried to be organized and applied in a certain philosophical integrity. Music Education within the scope of Art Education constitutes one of the most important branches of fine arts education as a qualified education (Yalçınkaya, 2010, p. 1).

Music education is the process of giving specific musical behaviors with the purpose of the individual. Music education is mainly aimed at three main purposes, general and volunteer (amateur) and professional no matter what the scope, content of the music, the content of the instrument, the instrument and the tool, the method and technique, the environment and the level is (Uçan, 2005, p. 30).

Instrument education in our country is given in institutions which provide professional music education. Institutions that train music teachers provide training for various instruments as individual instrument training (Lehimler, 2014, p. 2).

Instrument education is one of the most important and meaningful dimensions of music education in all levels whether it is for general, volunteer, or professional purposes in order for individuals to learn to play a musical instrument, to have the opportunity to train themselves in that musical instrument, and to enable individuals to benefit from playing that instrument in music education (Bulut \& Topaloğlu, 2012, p. 71) 
In the name of individual instrument training, cello education is one of the important instrument training fields given for 4 years as 8 semesters in music teaching department.

The most important materials aiming to give individual behaviors towards individual instrument playing are studies and exercises. This is because the ability to play the instrument is systematically acquired by the individual and this process requires intense mental and physical effort. Materials that systematically support all these processes are studies and exercises (Kaya, 2010, p. 2).

In addition, when the basic teaching principles, such as the from known to unknown, from close to far, from environment to the universe are considered, the importance of using traditional folk songs in music education and instrumental education emerges.

The ability of the music teacher candidate to express himself musically in his professional life and to provide a more qualified music education is directly proportional to the competence in his instrument. For this reason, in cello education, it is very important to acquire technical and musical behaviors in order to play cello correctly. Educational materials used in instrument training are important in this respect.

The most important music source that constitutes the music foundation of the societies is folk music. Turkish folk music has also developed and enriched with the accumulation of its history. When the Turkish folk music, which is rich in style, is examined, the richness of the syncopated styles beside the simple styles in the western music draws attention.

Songs of Black Sea region with 7-8 style, Zeibek belonging to the Aegean region with 9-4 style, folk songs of Şanliurfa with 10-8 style shows that works of syncopated style are the fundamental structure that reflect of the regional musical culture.

It is important for the music teacher candidates to be able to recognize, resolve, and perform such syncopated styles and modal folk songs as well as to define their own cultures and transfer them to their students in the future.

It is thought that the support of traditional Turkish music education through instrumental education with all field courses is very necessary in terms of forming a common culture and resources (Yalçınkaya, 2010, p. 3).

As far as instrumental education in Turkish music is concerned, until 20th century, there is no systematic way of educating student, and no study to give technical skills proper to the instrument and to improve the technical features of the instrument, and also there is no special repertoire written for instruments and no exercises were written (Değirmencioğlu, 2011, p. 30).

For this reason, repertoire, methodology and other materials including international performance techniques are used in music teacher education departments especially in cello training.

When examining the various musical education programs given in the institutions that train music teachers, it is seen that individual instrument education is based predominantly on western music and that Turkish music is not given enough importance (Lehimler, 2014, p. 7)

Kaya and Çilden (2010) stated that Turkish musical works, studies and exercises are not given sufficient importance in cello training in music education departments in Turkey, and that many cello students remarked the deficiencies and made recommendations and expressed this issue needs more attention.

Students mainly perform works and studies based on simple style and tonal sequences and have difficulties in performing traditional musical values such as modal sequences and syncopated styles.

This study is important in terms of the opinions of the instructors working in the department of music education in education faculty of fine arts education about the usage status of the folk music melodies (work or study) in the cello education, and determining and solving the problems that students have experienced in this issue, and also being a guide for further studies.

\subsection{The Purpose of the Study}

This study carried out in order to reveal the usage status of Turkish folk melodies of syncopated style in cello training by instructors who gave cello training in the music education faculties, the performance of the students on folk music of syncopated style, effects of readiness level on performance and to comment on suggestions related to the problems of this issue. For this purpose, the answers of the following questions were sought:

1) What are the opinions of the instructors regarding the suitability of the Turkish folk music melodies of syncopated style arranged for cello (work or study) in cello education? 
2) What are the opinions of the instructors regarding the adequacy of melodies used in accordance with sequences of folk music of syncopated style arranged for cello?

3) If instructor is using, what are the sources related to syncopated style and modal melodies arranged for a cello? How often are these resources used by the instructors in cello training?

4) What are the opinions of the instructors on the theoretical knowledge levels of the students in the cello education about the syncopated style and the Turkish folk music sequences?

5) What are the opinions of the instructors regarding the level of the students' ability to correctly perform folk music melodies of syncopated style according to its procedural structure?

6) What are the opinions of the instructors about the effect of the level of readiness of the right-handed bow techniques on performing Turkish folk music melodies of syncopated style?

7) What are the opinions of the instructors about the effect of the level of readiness of the left hand techniques on performing Turkish folk music melodies of syncopated style?

8) What are the opinions of the instructors about the effect of the level of readiness related to musical dynamics on performing Turkish folk music melodies of syncopated style?

9) What are the opinions of the instructors regarding the use of folk music melodies of syncopated style to increase or improve students' success?

10) What are the recommendations of the instructors to improve the performance of students to perform folk music melodies of syncopated style?

\section{Method}

\subsection{Research Design}

This study is qualitative study which aims to reveal the usage status of Turkish folk melodies of syncopated style in cello training by instructors who gave cello training in the music education faculties, the performance of the students on folk music of syncopated style, effects of readiness level on performance and to present suggestions related to the problems of this issue.

"Qualitative research can be defined as a research method using data gathering techniques such as observation, interview, and document analysis, which are based on the concept of constructing a theory and examining social phenomena in the environment they are connected to (Yıldırım \& Şimşek, 2013, p. 45). In the study, a semi-structured interview technique was used which is one of the data collection methods used in qualitative research.

In this technique, the responder has the right to partially correct or edit the questions prepared by the researcher. Questioner and responder may rearrange some questions together. As such, this technique can often be used in qualitative research (Sönmez \& Alacapınar, 2013, p. 108).

\subsection{Target and Sample of the Study}

The population of the study is instructors who give cello education in department of music education in fine arts faculty of education in Turkey. There are 18 instructors who give cello training in Turkey. The sample of the study is 13 instructors who want to participate in the interview. In this case, it can be said that about 3/4 of the population participated in the study.

Table 1. Personal information of participating instructors within the scope of the research

\begin{tabular}{llccc}
\hline & & Number (n) & $\%(\mathrm{f})$ \\
\hline Age & $31-40$ & 8 & & 62 \\
& 41 and over & 5 & Total & 100 \\
Educational & Associate degree & & & 0 \\
Background & Bachelor's degree & - & & 0 \\
& Master's degree & - & & 77 \\
& Phd degree & 3 & & 100 \\
& Profiency in Art & 10 & & 100 \\
& & - & Total & 0 \\
Field of Cello & Yes & 13 & & 100 \\
& No & - & Total & \\
& & & & \\
\hline
\end{tabular}




\begin{tabular}{|c|c|c|c|c|}
\hline \multirow[t]{5}{*}{ Experience } & $6-10$ & 1 & & 8 \\
\hline & $11-15$ & 4 & & 31 \\
\hline & $16-20$ & 3 & & 23 \\
\hline & 21 and over & 5 & & 38 \\
\hline & & & Total & 100 \\
\hline \multirow[t]{6}{*}{ Title } & Instructor & 2 & & 15 \\
\hline & Expert & 1 & & 8 \\
\hline & Assistant Professor & 6 & & 46 \\
\hline & Associate Professor & 3 & & 23 \\
\hline & Professor & 1 & & 8 \\
\hline & & & Total & 100 \\
\hline
\end{tabular}

When the distributions of age variables of the instructors participating in the survey are examined in Table 1; it can be said that a large part of $62 \%$ is in the age range of $31-40,38 \%$ is in the age of 41 and above. When the distribution of educational status variable is examined; it can be said that a great majority of $77 \%$ received doctoral education and $23 \%$ of had graduate education. All of the participants seem to be cello field specialists. When the distributions related to the experience variable are examined; A large percentage of $38 \%$ have 21 or more years, $31 \%$ have $11-15$ years and $23 \%$ have $16-20$ years of experience. In this case, it can be stated that the instructors participating in the research are very experienced. When the distributions related to the staff status variable of the participants are examined, it is seen that $46 \%$ of them are assistant professors, $23 \%$ are associate professors, $15 \%$ of them are instructors, $8 \%$ are professors and $8 \%$ are experts.

\subsection{Data Collection Tool}

The data were collected through a semi-structured interview form prepared in the direction of the research purpose with open-ended questions of qualitative research methods and personal information form. Before moving on to the preparation of the questionnaire, 10 open-ended interview questions were prepared in the light of the collected information from literature review.

\subsubsection{The Study of Validity and Reliability}

The 10 open ended questions prepared for the semi-structured interview form were first discussed and then edited by one assessment and evaluation specialist and two academicians from field specialists. The prepared draft form was tested on 3 academicians outside the scope of the research and the final form was given to the interview form.

\subsubsection{Receiving Expert Opinions}

The recorder was used to completely prevent data loss during interviews. Before the interview, participants were informed that the recorder would be used during the interview. As a result of informing, 6 participants did not want voice recorder to be used. For this reason, during the interview, the researcher took notes and recorded the data. In case of necessity, the data were recorded by asking the participants again for the purpose of preventing data loss. Each interview lasted approximately 20-25 minutes. During the interview, it was avoided to lead the instructors and to negatively affect the data collection process of the research.

\subsection{Data Analysis}

In the analysis of collected data, descriptive analysis method which is one of qualitative data analysis techniques was used." The obtained data are summarized and interpreted according to the previously determined theme. A direct citation may be included to effectively reflect the views of the interviewed or observed individuals. The purpose of such analysis is to present the findings to the reader in an organized and interpreted way. The obtained data are first described in a clear way. Then, these descriptions are explained and interpreted, cause-effect relationships are examined and some results are reached" (Yıldırım \& Şimşek, 2013 p.256). In the findings, important and high frequency opinions related to the topic are quoted directly. The codes K1, K2, K3 ... are used when direct opinions of the participants are given.

\subsection{Ethical Aspects of the Study}

Before the interview, participants were informed that the recorder would be used during the interview. During the interview, situations which may negatively affect the data collection process of the study and lead the instructors were avoided. 


\section{Findings}

3.1 Findings about the Suitability of Using Turkish Folk Music of Syncopated Style Arranged for Cello Training (Work or Study) in Cello Training

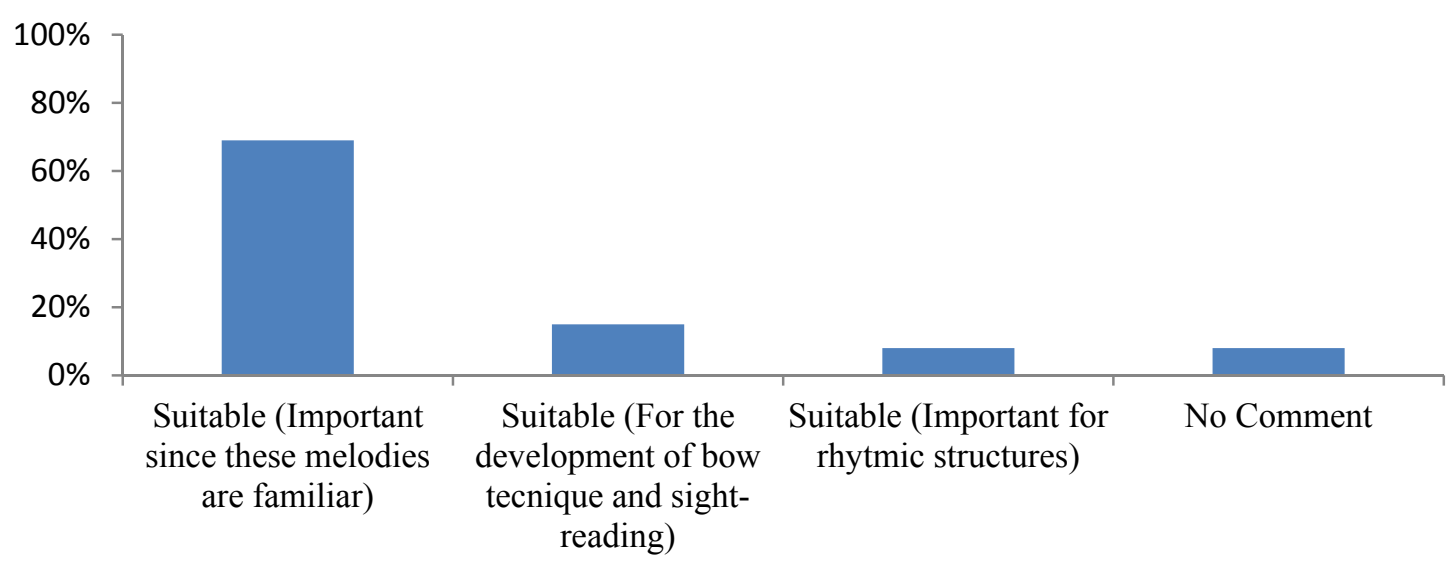

Figure 1. Participant instructor opinions on the suitability of using Turkish folk music of syncopated style arranged for cello training (work or study) in cello training

When Figure 1 is examined, group of $70 \%$ of participants argue that using these resources that are familiar to students will make their students more willing to learn. A group of $15 \%$ say that folk songs will contribute positively to students' development of bow techniques and sigh-reading. A group of 5\% indicated that folk music of syncopated style will enrich students in terms of rhythm. Some did not make any comment. A few of the instructors on the topic stated:

It is suitable." It is very suitable for students who are familiar with Turkish music to be provided with syncopated tunes" (K6).

It is suitable." Turkish society is more familiar to the Turkish folk songs" (K1).

"Playing folk songs which contains syncopated style provides a great contribution to the practice of the bow skill and bow techniques" (K9).

In this case, it can be said that as many as $90 \%$ of participating instructors stated positive opinion about the use of Turkish folk melodies of syncopated style in cello education.

3.2 Findings about Adequacy of Melodies Used in Accordance With Sequences of Folk Music of Syncopated Style Arranged for Cello

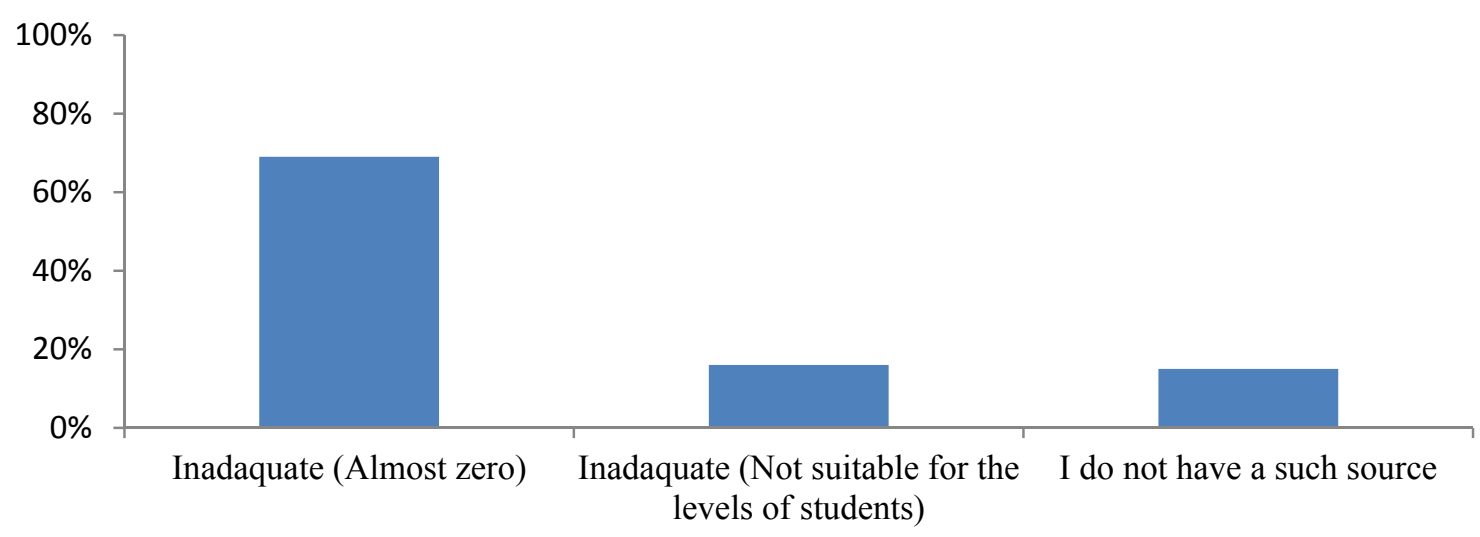

Figure 2. Opinions of instructors on the adequacy of melodies used in accordance with sequences of folk music of syncopated style arranged for cello 
When Figure 2 is evaluated, on average $70 \%$ of the instructors stated that such a source is almost zero and 15\% of them stated that the source is inadequate and existing sources are not suitable for the students. $15 \%$ of the instructors stated that they do not have any such source. A few of the instructors on the topic stated:

"It is not adequate" (K4).

"There is a source problem. I do not have enough sources on this topic" (K7).

"Works of syncopated style are not enough" (K3).

In this case, it can be stated that all of the participating faculty members expressed their views on the lack and the inadequacy of sources of syncopated style.

3.3 Findings Related to the Frequency and Types of Sources Containing Syncopated Style and Modal Melodies (Works or Studies) Used in Cello Education

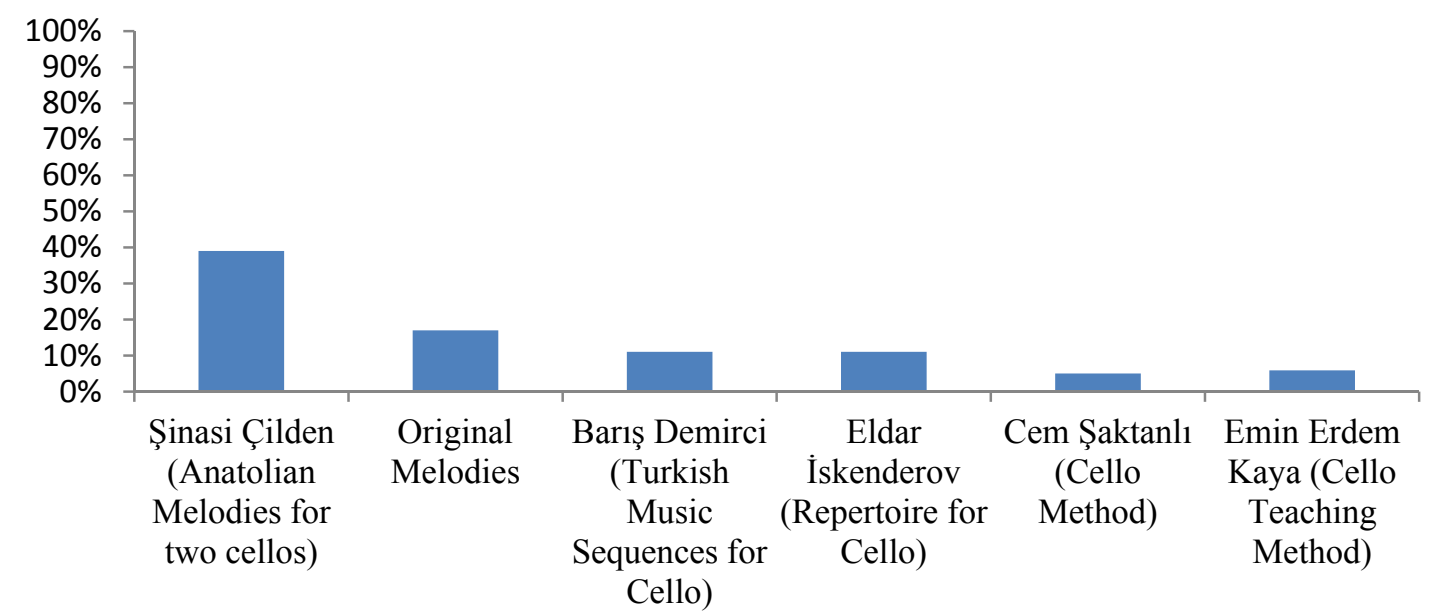

Figure 3. Participant instructor opinions on type and frequency of sources containing syncopated style and modal melodies (works or studies) used in cello education

As can be seen in Figure 3, it can be said that the book of Şinasi Çilden titled" Anatolian Melodies for Two Cellos" is used by a large part of around $40 \%$ of the instructors participating in the research and $15 \%$ of them use their original melodies. It can also be said that Barış Demirci's" Turkish Music Sequences for Cello", Eldar İskenderov's" Repertoire for Cello", Cem Şaktanlı's" Cello Method" and Emin Erdem Kaya's" Cello Teaching Method" are used less frequently.

According to the opinions of the participating instructors, nonconformity to the student level of inadequate sources with syncopated style and modal sequences that are used in the cello education negatively affect the frequency of use of these sources. A few of the instructors on the topic stated:

"The only source related to the Turkish music that I use is Şinasi Çilden's" Anatolian Melodies for Two Cellos" book" (K7).

"Sometimes I try to use Anatolian melodies for two cellos. Folk songs for cello that I have adapted it to the level of the students" (K9). 
3.4 Findings of the Theoretical Knowledge Levels of the Students in Cello Education about Syncopated Style and the Turkish Folk Music Sequences

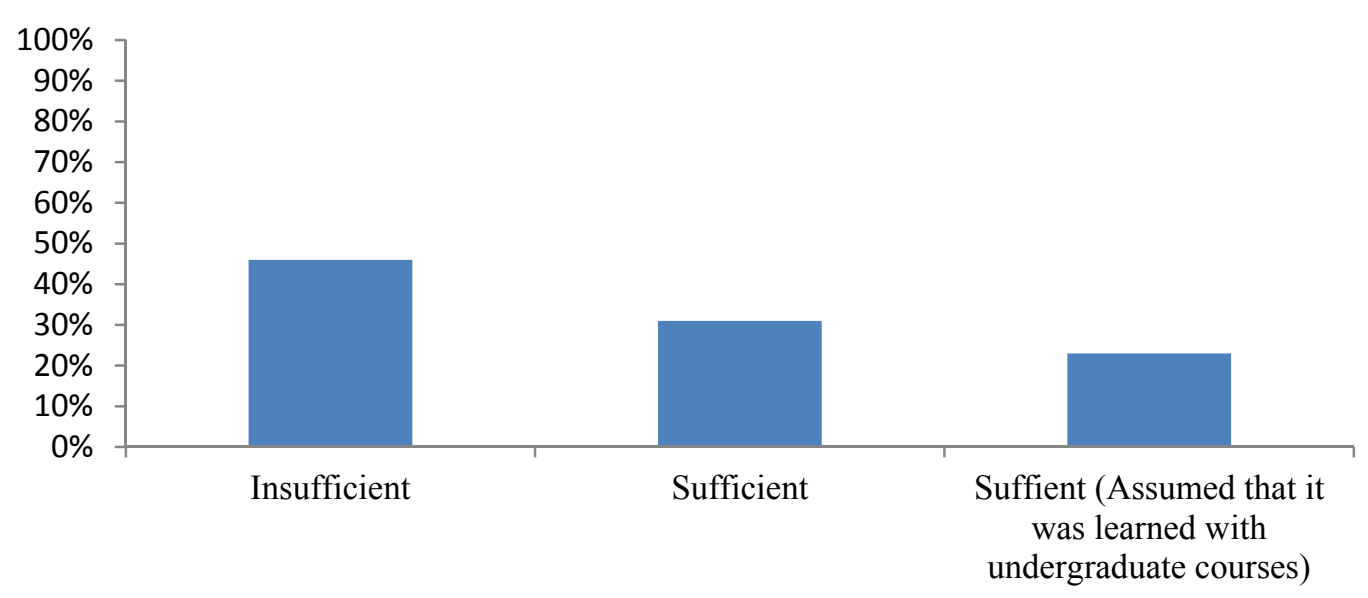

Figure 4. Participant instructor opinions on theoretical knowledge levels of the students in the cello education about syncopated style and the Turkish folk music sequences

When Figure 4 is evaluated, it is seen that $45 \%$ of the instructors participating in the research stated that the theoretical knowledge levels of the students are insufficient. 30\% reported that theoretical knowledge levels of the students are sufficient, while $25 \%$ stated that they assumed that the students know these subjects since they have taken related undergraduate courses. A few of the instructors commented on the subject:

"Instead of thinking about cello education, we can say in the general sense that the theoretical levels are moderate. Because they take course of Turkish folk music" (K2).

"They know some easy modes as tampere. They also have basic knowledge about the syncopated styles" (K4).

"There is even lacking in western music theories, and we cannot say that they have good levels of knowledge about folk music and syncopated styles." (K6).

In this case, it can be said that $55 \%$ of the participating instructors stated that the theoretical knowledge levels of the students about the syncopated style and the Turkish folk music sequences are sufficient.

3.5 Findings about the Level of Correct Performance of Students in Accordance with Procedural Structure of Folk Music Melodies of Syncopated Style in Cello Education

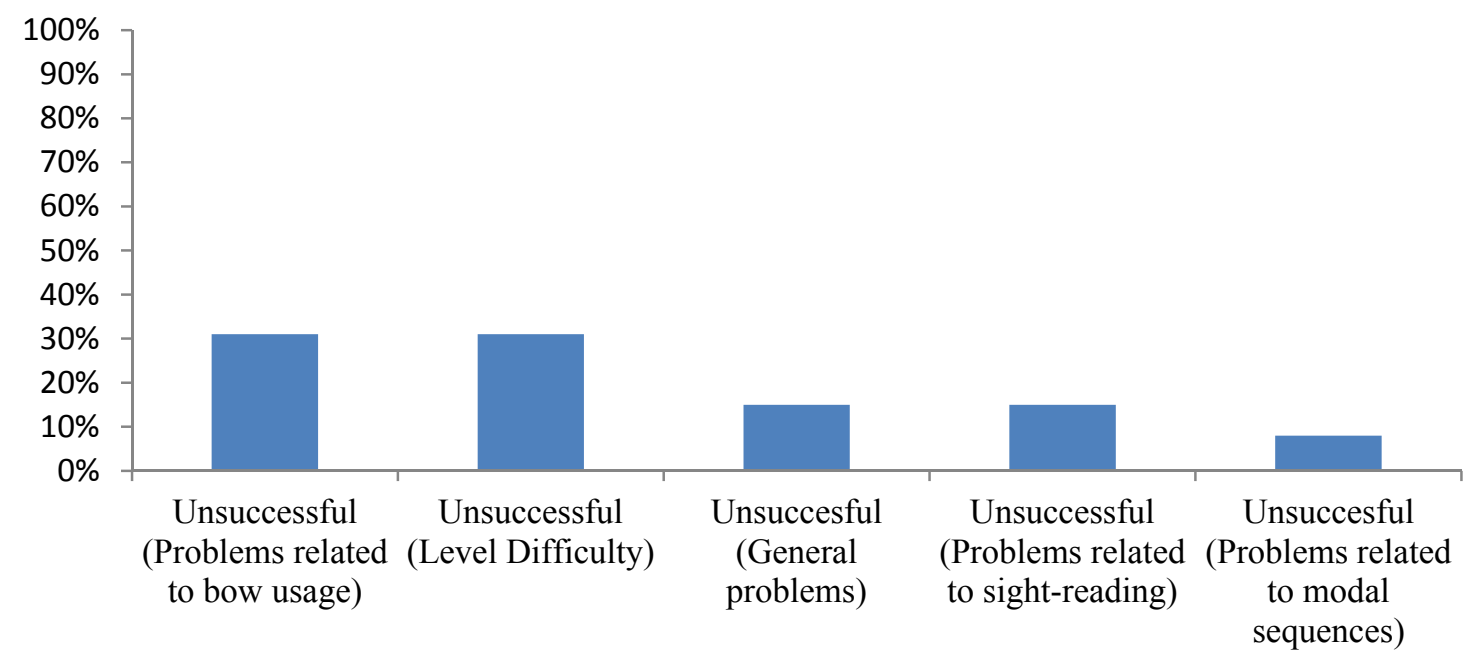

Figure 5. A table of participant instructor opinions on the level of correct performance of students in accordance with procedural structure of folk music melodies of syncopated style in cello education 
When Figure 5 is evaluated, it is seen that all of the teaching staff who participated in the study stated that students could not correctly perform the folk songs of syncopated style $30 \%$ of the instructors indicated there are problems related to bow, $30 \%$ emphasized the level of difficulty, $15 \%$ stated sight-reading problems, $15 \%$ indicated general problems and 5\% stated modal sequences as the reasons of failure of the students to perform correctly. A few of the instructors commented on the subject:

"Sight-reading stage is very difficult and most of the time they fail" (K9).

"They have difficulty in bow technique, but they can adapt in a short time" (K3).

"Because we do not have enough resources, we cannot include these songs in the course content, since the available sources are not suitable for student levels" (K1).

In this case, it can be said that all of the participating faculty members stated that students did not properly perform folk music melodies of syncopated style in accordance with its procedural structure, and students had more problems with the use of bow and sight-reading.

3.6 Findings about the Effects of Students' Readiness Levels of Right Hand Bow Techniques on Performing Turkish Folk Music Melodies of Syncopated Style

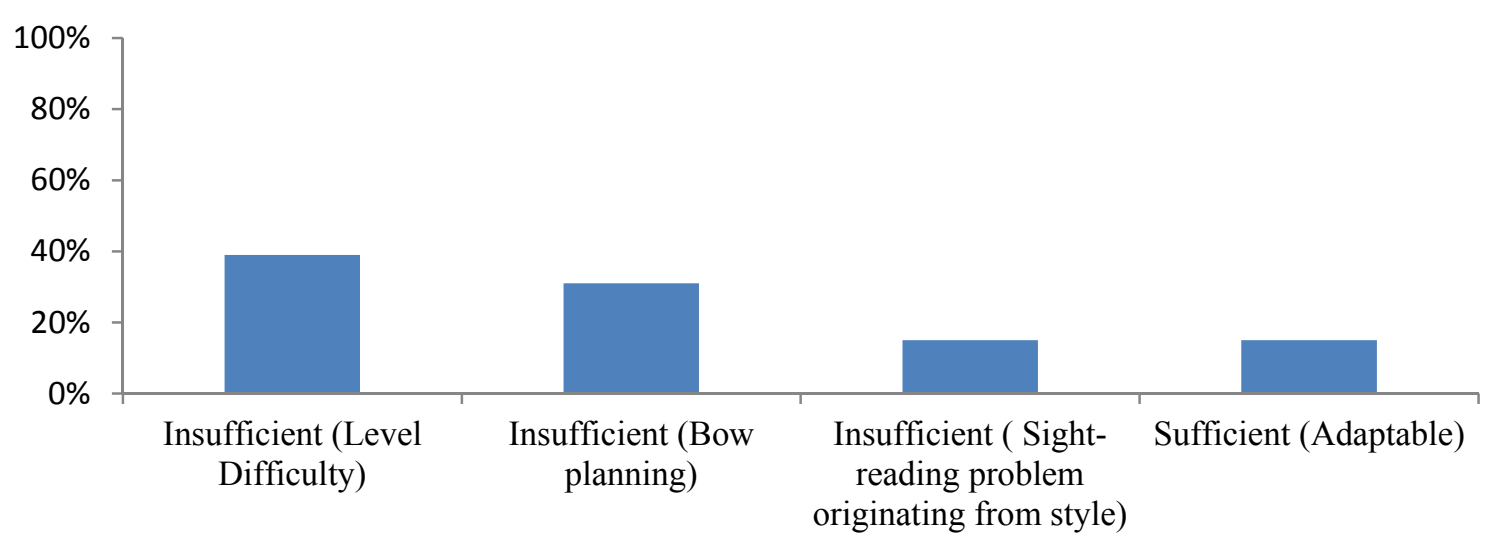

Figure 6. Participant instructor opinions on the effects of students' readiness levels of right hand bow techniques on performing Turkish folk music melodies of syncopated style

When Figure 6 is evaluated, it is seen that $40 \%$ of the instructors who participated in the research stated students have difficulties since melodies are not suitable for the levels of them, $30 \%$ of said that they can not do bow planning and $15 \%$ stated students have difficulties due to sight-reading problems. Group of $15 \%$ stated that students are not at sufficient level in terms of right hand technique. A few of the instructors commented on the subject:

"Help is needed on how to use bow, which parts of the bow will be more appropriate to use. I mean, it can not be said that the readiness levels are sufficient" (K9).

"There are problems with how to use the bow. In this regard, we help them" (K10).

"I think that the students' levels of readiness in folk music melodies are adequate in terms of bow technique" (K4).

In this case, it can be said that a great majority of $85 \%$ of the participating instructors stated that the experience on right handed bow techniques of the students was insufficient to perform the folk melodies of syncopated style, and students have difficulty in bow planning mostly. 
3.7 Findings about the Effects of Students' Readiness Levels of Left Hand Techniques on Performing Turkish Folk Music Melodies of Syncopated Style

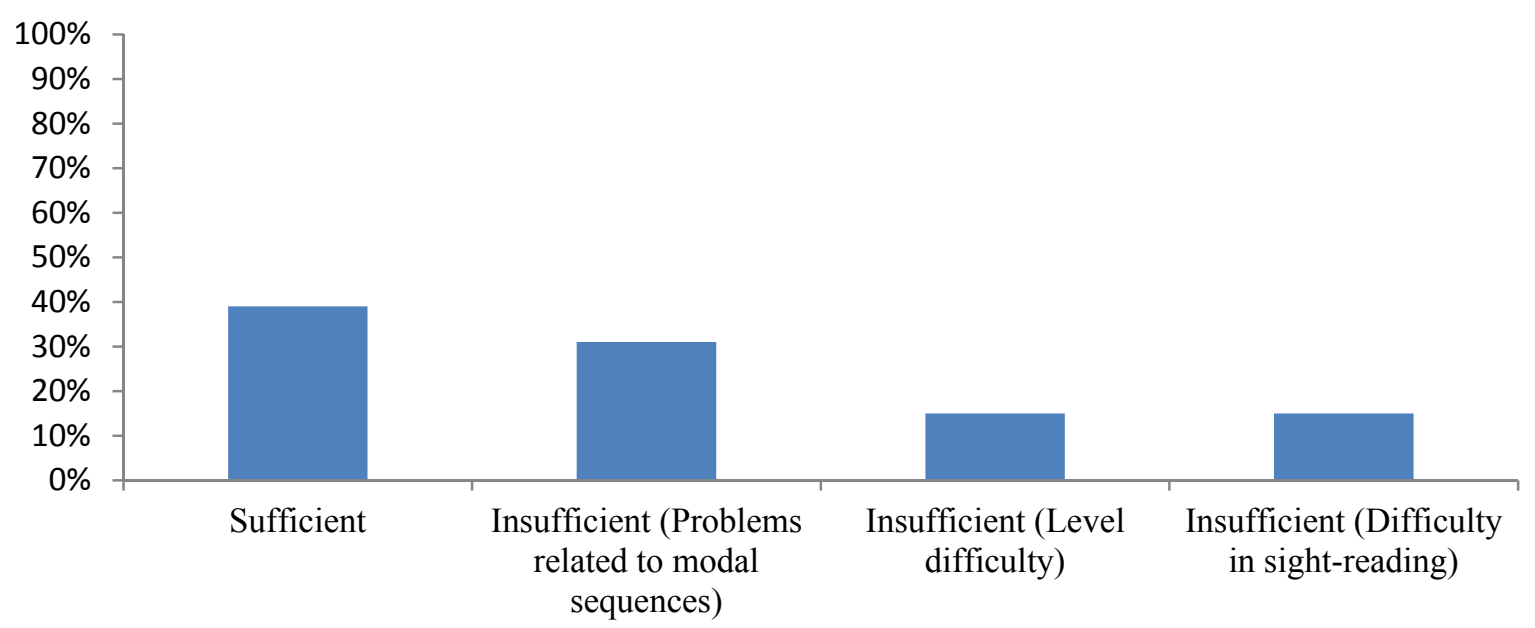

Figure 7. Participant instructor opinions on the effects of students' readiness levels of left hand techniques on performing Turkish folk music melodies of syncopated style

When Figure 7 is evaluated, it is seen that about $40 \%$ of the instructors participating in the research stated that the students are at sufficient level. A group of $30 \%$ who believed that the left hand technique of students was inadequate reported that students have problems with position shifts especially in modal sequences, a group of $15 \%$ stated that melodies are above the students' level and $15 \%$ of them said that students have difficulty in sight-reading. A few of the instructors commented on the subject:

"They may have difficulty at first, but they can overcome" (K2).

"I think there are different intervals in the Turkish music such as 1.5 jumps in relation to the left hand and these positions have to be ready. In Western music, harmonic minorities are involved, but in this case it is important to prepare fingers. There is much distance between finger which is outside of the nature. This situation is the signal of a bigger problem than the right hand" (K6).

Accordingly, it can be said that $60 \%$ of the participating instructors stated that the experience in left hand techniques is not enough for the students to perform folk music melodies of syncopated style and that the students have problems about the position shift in the modal sequences.

3.8 Findings about the Effects of Students' Readiness Levels of Musical Dynamics on Performing Turkish Folk Music Melodies of Syncopated Style

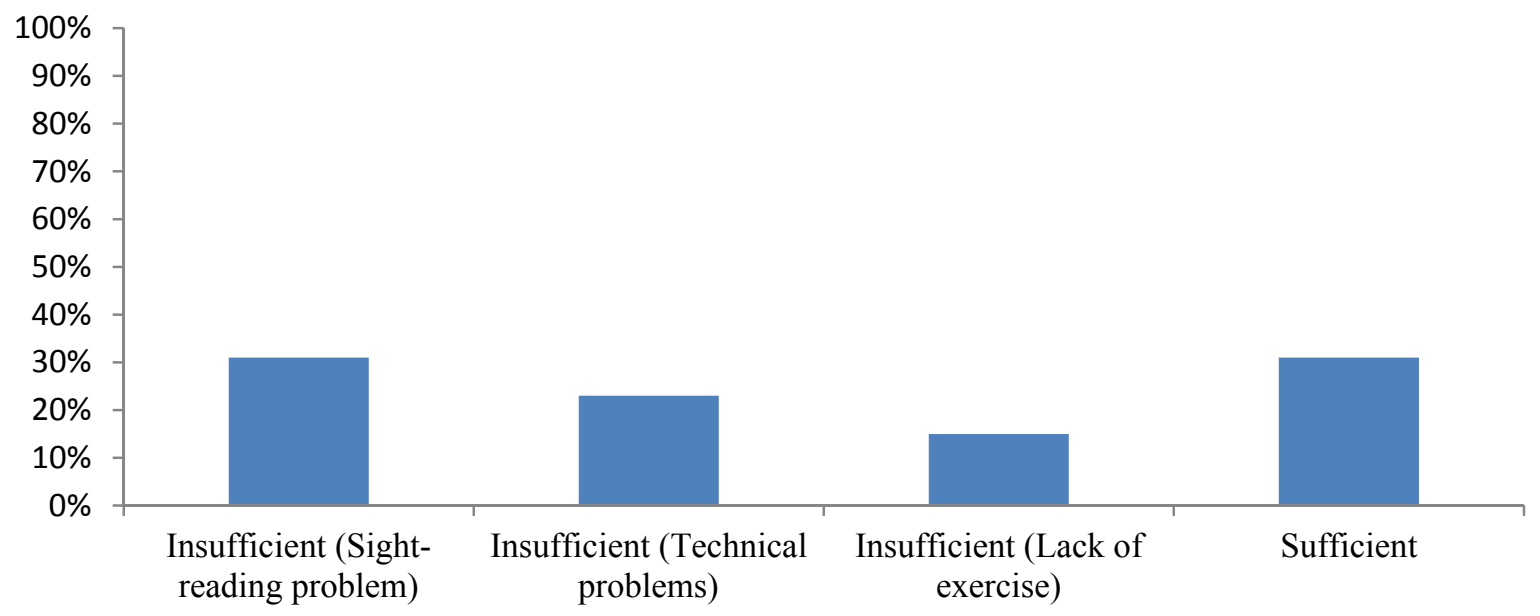

Figure 8. A table of participant instructors' opinions on the effects of students' readiness levels of musical dynamics on performing Turkish folk music melodies of syncopated style 
When Figure 8 is evaluated, it is seen that $30 \%$ of the instructors participating in the research stated that students are inadequate and have difficulty in sight-reading, a group of $25 \%$ expressed technical problems and a group of $15 \%$ stated students are having problems due to lack of exercise. A few of the instructors commented on the subject:

"I have no clear idea since such sources are insufficient. Generally speaking, it is difficult for the students to adapt to this situation because students are not used to the structure of modal melody and syncopated scale. The musicality remains on the background because the student is trying to understand the work" (K7).

"I think positively. However, enough exercise should be made" (K8).

Accordingly, it can be said that a large part of $70 \%$ of the participating instructors stated that the experience of students' in musical dynamics was insufficient, and that students are having difficulty in performing musical dynamics due to technical problems and problem in sight-reading.

3.9 Findings about the Use of Folk Music Melodies of Syncopated Style to Increase or Improve Students' Success

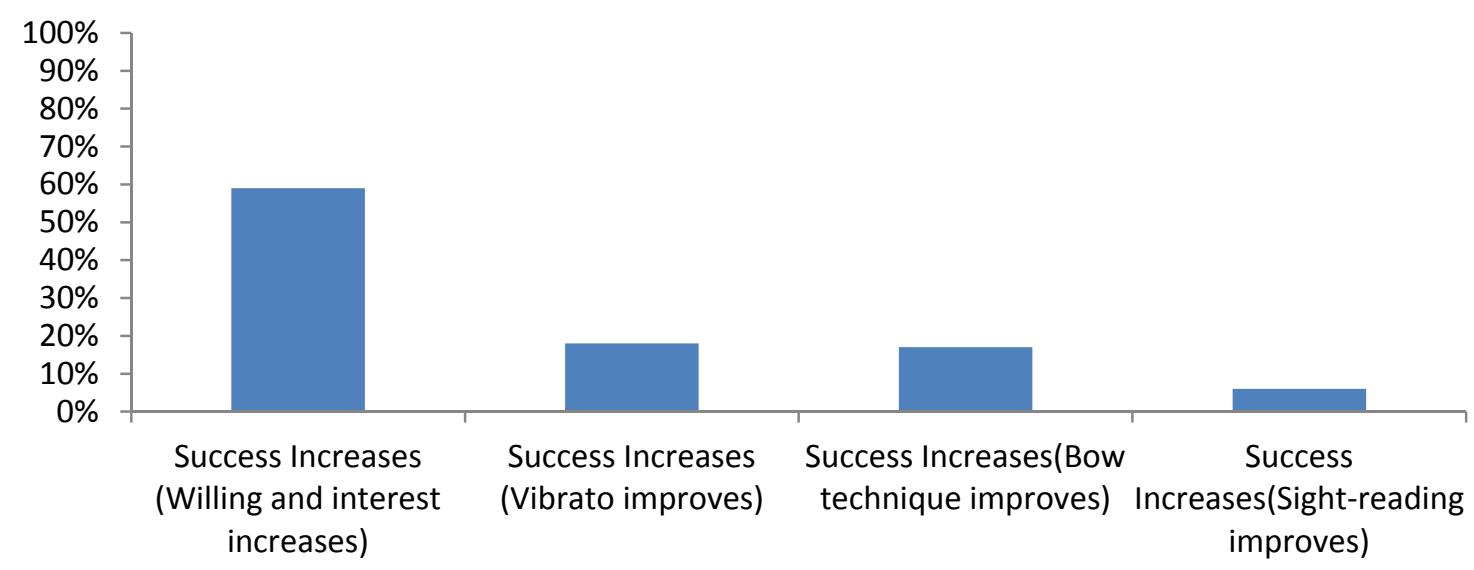

Figure 9. Findings about the use of folk music melodies of syncopated style to increase or improve students' success

When Figure 9 is evaluated, it is seen that all of the instructors who participated in the research stated that the use of folk music melodies of syncopated style in cello education increased or will increase students' success. Approximately $60 \%$ of respondents agree that this kind of melody will increase students' willingness to work, a group of $15 \%$ stated that it will improve vibrato technique, a group of $15 \%$ stated that it will improve bow technique, and a group of $5 \%$ stated that it will improve sight-reading. A few of the instructors commented on the subject:

"I think that using Turkish folk songs in education will have a positive effect. Students are more willing to play these tunes" (K1).

"I think it will develop the bow. It can enrich the technique. We can tell that students will work more with pleasure" (K10).

"From the works they have learned, its contribution to bow technique and also to the vibrato technique may be much greater" (K6). 
3.10 Findings about the Recommendations of the Instructors to Improve the Performance of Students to Perform Folk Music Melodies of Syncopated Style

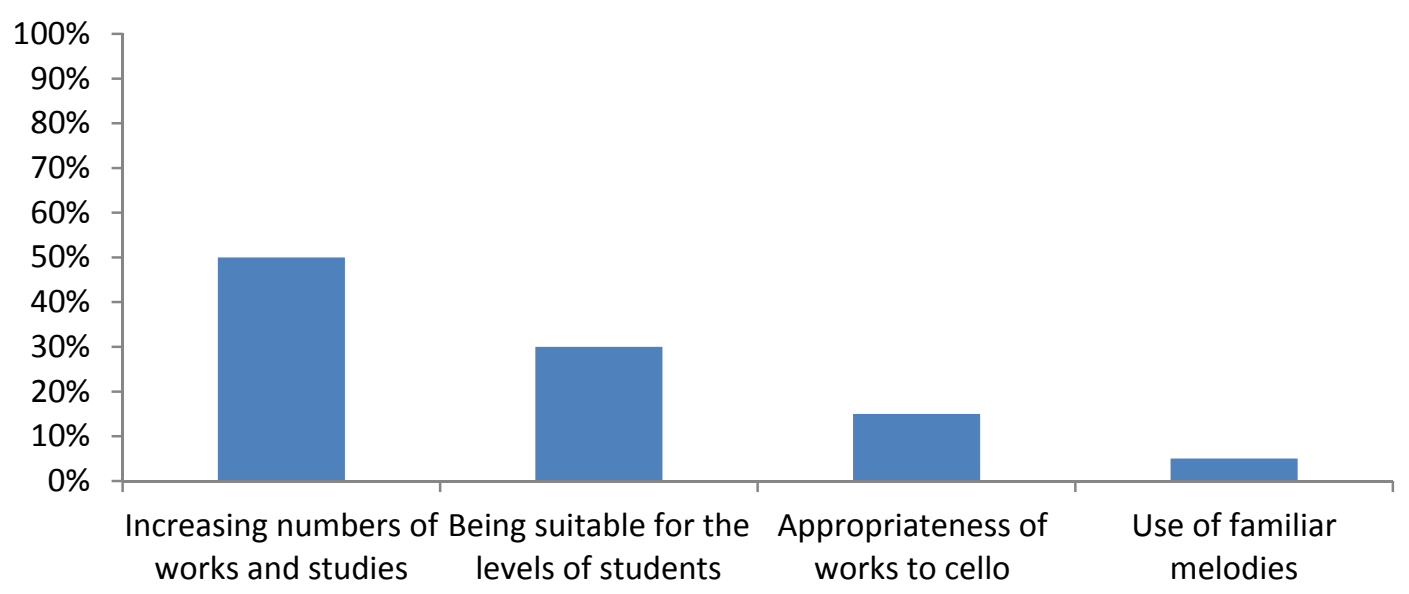

Figure 10. Findings about the recommendations of the instructors to improve the performance of students to perform folk music melodies of syncopated style

When Figure 10 is evaluated, it is seen that $50 \%$ of the instructors stated that number of works and studies should be increased, $30 \%$ stated that works and studies should be formed according to the students' level, $15 \%$ stated that melodies should be selected appropriate to the cello, and $5 \%$ stated that melodies that are familiar to the students should be used. A few of the instructors commented on the subject:

"One of the most important requirements of the principle of" going out from the individual's experience", which is one of the basic principles of instrument education, is to make use of folk music for rhythmic and modal purposes in cello education" (K3).

"I think it would be appropriate to increase the sources arranged for the cello and arrange it according to the levels of the students" (K12).

"I observe that there is a problem to find sources in Turkey. If I had a source, I would think of playing with the students" (K5).

In this case, it can be said that the participants emphasized the lack of sources.

\section{Results and Discussion}

In this section, the results obtained in the direction of the findings obtained and the recommendations developed in the light of these results are given

According to the findings of the research, the conclusions are as follows;

1 Results on the suitability of using Turkish folk music of syncopated style arranged for cello training (work or study) in cello training;

When the opinions of the instructors participating in the research are evaluated, it is seen that the use of Turkish folk music of syncopated style arranged for cello training (work or study) in cello training will primarily help the students to be more willing to learn, will be useful for the development of the sight-reading skills and contribute to the development of the limited repertoire.

2. Result on adequacy of melodies used in accordance with sequences of folk music of syncopated style arranged for cello

It can be concluded that Turkish folk music of syncopated style arranged for cello training (work or study) is not useful in cello training because the number of these works is limited and there is a nonconformity between students' level and this repertoir.

3. Results related to the frequency and types of sources containing syncopated style and modal melodies (works or studies) used in cello education 
The sources used by the instructors for the training of Turkish folk music melodies of syncopated style (works or studies) are as follows: Şinasi Çilden's" Anatolian Melodies for Two Cellos", Barış Demirci's" Turkish Music Sequences for Cello", and Eldar İskenderov's" Repertoire for Cello, Vol. 1". At the same time, besides the books used by, it is seen that instructors write authentic studies for playing the Turkish folk music melodies of syncopated style

4. Results on he theoretical knowledge levels of the students in cello education about syncopated style and the Turkish folk music sequences

Although the theoretical knowledge of the students about the syncopated style and the Turkish folk music sequences is reached at a sufficient level with the undergraduate courses, it is seen that the students fail to perform this information because they do not exercise enough about the subject.

5. Results on the level of correct performance of students in accordance with procedural structure of folk music melodies of syncopated style in cello education

When the problems that the students are experiencing in performing these melodies are examined, problems such as bow use, level difficulty, problem of sight-reading, position shift in modal sequences appear.

6. Results on the effects of students' readiness levels of right hand bow techniques on performing Turkish folk music melodies of syncopated style

It seems that students' experience in right-handed technical is often inadequate to perform these melodies and that these problems occur mostly due to nonconformity between melodies and the students' levels, use of bow and sight-reading.

7. The results on the effects of students' readiness levels of left hand techniques on performing Turkish folk music melodies of syncopated style

It is seen that the left-hand technical experience of the students is often inadequate to perform these melodies, and the problems that the students have experienced about the left hand techniques are position shifts in modal sequences, sight-reading and level difficulties.

8. The results on the effects of students' readiness levels of musical dynamics on performing Turkish folk music melodies of syncopated style

It can be said that the students have a great problem in applying musical expressions because experience in right and left hand techniques is not enough to perform these melodies and students do not exercise enough.

9. Result on the use of folk music melodies of syncopated style to increase or improve students' success

According to the opinions of the instructors, it can be said that the use Turkish folk music melodies of syncopated style in the cello education will increase the student's success by improving vibrato, bow and sight-reading techniques and also by making them to study more willingly.

10. The results on the recommendations of the instructors to improve the performance of students to perform folk music melodies of syncopated style

It is emphasized by participating instructors that it is important to increase the number of works and studies arranged for the cello in accordance with the levels of the students and that the folk songs planned to be adapted to the cello should be selected according to the technical structure of the cello and that the repertoire which is formed in a simpler way may be more useful.

The suggestions made in line with the results of the research are listed below;

1. More frequent use of Turkish folk music products in cello education, as the use of known melodies will lead students to work more willingly.

2. Increasing the methodical work for the realization of permanent learning by giving the students the opportunity to apply the theoretical knowledge of Turkish music products in cello education.

3. Choosing folk songs that are appropriate for the structure of cello while making a repertoire

4. Simplifying and organizing the selected songs to be used in cello education to the levels of the students

5. Including works and studies of Turkish and world music with syncopated style together with simple scaled studies and works in cello education

6. Taking student opinions about the use of the Turkish music products with syncopated style and assessing the issue with that point of view. 
7. Evaluation other instruments as in this study.

\section{Acknowledgements}

This study was produced from a part of PhD thesis prepared by Taner TOPALOĞLU at the Department of Fine Arts Education, Music Education Programme in Gazi University Educational Sciences Institute.

\section{References}

Bulut, D., \& Topaloğlu, T. (2012). J. J. F. Dotazuer viyolonsel metode birinci kitabının hedef ve hedef davranışlar yönünden incelenmesi. Dicle Üniversitesi Ziya Gökalp Eğitim Fakültesi Dergisi, 18, 69-81.

Değirmencioğlu, L. (2011). Makamsal viyolonsel öğretim yöntemine sistematik bir yaklaşım (Unpublished doctoral dissertation). İnönü Üniversitesi, Eğitim Bilimleri Enstitüsü, Malatya.

Kaya, E. E. (2010). Müzik öğretmeni yetiştiren kurumlarda makamsal etüt ve egzersizlerle viyolonsel eğitiminin uygulanabilirliği (Unpublished doctoral dissertation). Selçuk Üniversitesi, Sosyal Bilimler Enstitüsü, Konya.

Kaya, E. E., \& Çilden, Ş. (2010). Türkiye'deki Üniversitelerin Müzik Öğretmeni Yetiştiren Anabilim Dallarındaki Viyolonsel Eğitiminde Türk Müziği Ürünlerinin Kullanım Durumlarının İncelenmesi. Kelesoglu Education Faculty (AKEF) Journal, 29, 65-82. Retrieved from www.acarindex.com/ahmet-kelesoglu-education-faculty-akef-journal/turkiyedeki-universitelerin-muzik-ogr etmeni-yetistiren-anabilim-dallarindaki-viyolonsel-egitiminde-turk-muzigi-urunlerinin-kullanim-durumlarin in-incelenmesi-1175\#.W5Do0egzbIU

Lehimler, E. (2014). Geleneksel Türk müziğine dayalı viyolonsel ögretimine yönelik bir model önerisi ve uygulamadaki görünümü (Hüseyni Makamı Örneği) (Unpublished doctoral dissertation). Gazi Üniversitesi, Eğitim Bilimleri Enstitüsü, Ankara.

Nacakçı, Z. (2002). Türk halk müziği eserlerinin viyola eğitiminde kullanilabilirliği (Unpublished master’s thesis). Yüzüncü Yıl Üniversitesi, Sosyal Bilimler Enstitüsü, Van.

Sönmez, V., \& Alacapınar, G. F. (2013). Örneklendirilmiş Bilimsel Araştırma Yöntemleri. Ankara: Anı Yayincilik.

Uçan, A. (2005). Müzik Eğitimi. Ankara: Evrensel Müzik Evi

Yalçınkaya, B. (2010). Flüt eğitiminde geleneksel Türk müziği eserlerinin seslendirmesine yönelik oluşturulan" etüt yazma" modeli ve bu modelle bestelenen" özgün etütler" in öğrenci başarıs üzerine etkisi (Unpublished doctoral dissertation). Gazi Üniversitesi, Eğitim Bilimleri Enstitüsü, Ankara.

Yıldırım, A., \& Şimşek, H. (2013). Sosyal Bilimlerde Nitel Araştırma Yöntemleri. Ankara: Seçkin Yayıncılık.

\section{Copyrights}

Copyright for this article is retained by the author, with first publication rights granted to the journal.

This is an open-access article distributed under the terms and conditions of the Creative Commons Attribution license (http://creativecommons.org/licenses/by/4.0/). 